\title{
Green Life Style Sebagai Mediator Ecoliteracy dan Green Product Knowledge Terhadap Keputusan Pembelian Konsumen di Kota Ambon
}

\author{
Saul Ronald Jacob Saleky ${ }^{1}$, Wendy Souisa ${ }^{2}$ \\ ${ }^{1}$ Politeknik Negeri Ambon. Email: saulsaleky@gmail.com \\ ${ }^{2}$ Politeknik Negeri Ambon. Email: souisawendy@gmail.com
}

\begin{abstract}
To meet the needs and desires, consumers make decisions on the purchase of certain products. In making decisions, consumers are affected and consider many factors. This study aims to examine and analyze the effect of ecoliteracy and green product knowledge to the green lifestyle and purchasing decisions, either directly or indirectly. These results indicate that all independent variables have an effect on the dependent variable. Eco-literacy and green product knowledge have a direct influence on the green lifestyle and purchasing decisions. Furthermore, green lifestyle has a direct influence on consumer purchasing decisions in Ambon City. Similarly eco-literacy and green product knowledge has no direct influence on purchasing decisions through a green lifestyle. These results indicate that the directly effect of eco-literacy and green product knowledge was greater than the indirectly effect of through a green lifestyle. This means that the consumer's decision to buy a green product is more influenced by eco-literacy and green product knowledge than green lifestyle. Therefore, in order to encourage consumers more broadly to make purchases of green product, it would be better and easier for marketers and or manufacturers to enhance the eco-literacy and green product knowledge of the consumer.
\end{abstract}

Keywords: Eco-literacy, Green Product Knowledge, Green Lifestyle, buying decision

\begin{abstract}
Abstrak
Untuk memenuhi kebutuhan dan keinginannya, konsumen melakukan pengambilan keputusan atas pembelian produk tertentu. Dalam melakukan pengambilan keputusan itu, konsumen dipengaruhi dan mempertimbangkan banyak faktor. Penelitian ini bertujuan untuk menguji dan menganalisis pengaruh ecoliteracy, green product knowledge terhadap green lifestyle dan keputusan pembelian, baik secara langsung maupun tidak langsung. Hasil penelitian ini menunjukan bahwa semua variabel bebas memiliki pengaruh terhadap variabel terikat. Ecoliteracy dan green product knowledge memiliki pengaruh secara langsung terhadap green lifestyle dan keputusan pembelian. Selanjutnya green lifestyle memiliki pengaruh secara langsung terhadap keputusan pembelian konsumen di Kota Ambon. Demikian pula ecoliteracy dan green product knowledge memiliki pengaruh secara tidak langsung terhadap keputusan pembelian melalui green lifestyle. Hasil penelitian ini menunjukan bahwa pengaruh secara langsung ecoliteracy dan green product knowledge ternyata lebih besar daripada pengaruh tidak langsung melalui green lifestyle. Hal ini berarti bahwa keputusan konsumen untuk melakukan pembelian suatu green product lebih banyak dipengaruhi oleh ecoliteracy dan green product knowledge daripada green lifestyle. Oleh karena itu, untuk bisa mendorong konsumen secara lebih luas untuk melakukan pembelian terhadap green product, akan lebih baik dan lebih mudah bagi pemasar dan atau produsen untuk meningkatkan ecoliteracy dan green product knowledge dari konsumen.
\end{abstract}

Kata Kunci: Ecoliteracy, Green Product Knowledge, Green Lifestyle, Keputusan Pembelian.

\section{Pendahuluan}

Pemanasan global membuat masyarakat semakin berhati-hati dalam menggunakan berbagai produk yang dikhawatirkan dapat menambah level pemanasan global yang tentu saja akan membahayakan manusia. Sementara itu, kepedulian masyarakat terhadap lingkungan dan kesehatan pun semakin tinggi, yang membuat tuntutan masyarakat akan kualitas produk atau jasa semakin meningkat. Hal ini kemudian memunculkan beberapa faktor yang mendorong perusahaan menjadi lebih pro-lingkungan, antara lain kebijakan perdagangan, termasuk perdagangan internasional, yang semakin pro-lingkungan, seperti ecolabelling, serta tekanan dari lembaga swadaya masyarakat yang peduli lingkungan dan sorotan dari media. 
Berkaitan dengan menjaga kelestarian lingkungan, bukti yang ada menunjukkan sekitar $30-40 \%$ ketidakseimbangan lingkungan disebabkan oleh aktifitas konsumsi yang dilakukan oleh konsumen rumah tangga (Tilikidou, 2008). Kondisi demikian mendorong konsumen untuk semakin sadar terhadap lingkungan sekitarnya. Saat ini, sudah banyak konsumen yang sadar tentang kewajiban menjaga keseimbangan dan kelestarian lingkungan. Bentuk kesadaran tersebut diungkapkan dalam pencarian produk-produk yang ramah lingkungan.

Isu perubahan iklim merubah cara pandang konsumen menjadi lebih aware terhadap lingkungan. Sementara itu, mayoritas konsumen menyadari bahwa perilaku pembelian mereka secara langsung berpengaruh pada berbagai masalah lingkungan (Capra, 2011). Konsumen beradaptasi dengan situasi ini dengan mempertimbangkan isu lingkungan ketika berbelanja dan melalui perilaku beli mereka.

Semakin parahnya kerusakan lingkungan yang terjadi, diperkuat dengan perkembangan pesat teknologi informasi yang mendorong terciptanya "konsumen global", diprediksikan dalam periode waktu yang tidak terlalu lama jumlah konsumen berwawasan lingkungan di Indonesia akan meningkat pesat (Orr, 2011).

Green Purchasing adalah keputusan pembelian yang didasarkan pada prinsip lingkungan dan merupakan praktek dalam menerapkan kriteria lingkungan ke dalam pemilihan produk atau jasa yang ingin dibeli. Green purchasing adalah pengadaan barang-barang atau jasa yang memiiki dampak minimal terhadap lingkungan (Orr, 2011). Perumusan strategi green purchasing bukan masalah sederhana karena dapat mengakibatkan peningkatan biaya bahan baku dan adanya pemasok berkualitas yang mungkin terbatas karena kebutuhan untuk bahan non-tradisional.

Sejalan dengan itu, usaha pembangunan berkelanjutan yang dilakukan oleh masyarakat dengan pemahaman yang memadai tentang hakikat dan prinsip ekologi yang disebut ecological literacy atau ecoliteracy. Paradigma tentang ecoliteracy untuk menciptakan pemahaman masyarakat akan pentingnya kesadaran ekologis global, sehingga ada keseimbangan antara kebutuhan masyarakat dengan batas kekuatan lingkungan (Lorenzen, 2012).

Ecoliteracy membuat berbagai pihak memiliki pengetahuan tentang lingkungan sehingga timbul keinginan untuk terlibat dalam menjaga lingkungan yang diawali dengan gerakan konsumerisme global untuk menyadarkan konsumen akan hak-hak mereka untuk mendapatkan produk yang layak dan aman. Adanya gerakan tersebut, setiap individu harus memberikan kontribusi dalam kegiatan menyelamatkan bumi dari bencana lingkungan yang menakutkan karena telah mendapatkan informasi yang cukup dalam kehidupan sehari-hari, baik dari pihak konsumen dengan cara melakukan pembelian hijau (green purchasing) ataupun dari pihak produsen dengan cara melakukan pemasaran hijau (green marketing).

Ecoliteracy adalah cara berpikir tentang kesadaran lingkungan secara global yang berguna untuk menciptakan keseimbangan antara kebutuhan masyarakat dan kemampuan alam, termasuk dalam mempertimbangkan konsekuensi dari tindakan manusia dan interaksi dalam konteks alami (Tilikidou, 2008). Pada hakekatnya, tujuan dari ecoliteracy adalah membangun kesadaran akan gangguan ekosistem ke dalam pikiran masyarakat, membuatnya menjadi pusat perhatian dan kajian bagi lembaga-lembaga yang berwenang untuk meningkatkan perhatiannya (Capra, 2011). Adapun aspek-aspek ecoliteracy (Tilikidou, 2008) yaitu: Prinsip-prinsip dari sistem kehidupan, desain terinspirasi oleh alam, sistem berpikir, paradigma ekologi dan transisi untuk kolaborasi keberlanjutan, dan membangun komunitas dan kewarganegaraan.

Gaya hidup hijau (green lifestyle) termasuk praktik yang digunakan orang saat ini mencoba untuk mengatasi serangkaian masalah lingkungan, antara lain seperti perubahan iklim dan kenaikan permukaan air laut, polusi udara dan air, dan peningkatan ukuran tempat pembuangan sampah (Lorenzen, 2012).

Penelitian ini bertujuan untuk :

a. Menguji dan menganalisis pengaruh secara langsung Eco-Literacy terhadap Green Lifestyle. 
b. Menguji dan menganalisis pengaruh secara langsung Eco-Literacy terhadap Keputusan Pembelian.

c. Menguji dan menganalisis pengaruh secara langsung Green Product Knowledge terhadap Green Lifestyle.

d. Menguji dan menganalisis pengaruh secara langsung Green Product Knowledge terhadap Keputusan Pembelian.

e. Menguji dan menganalisis pengaruh Green Lifestyle terhadap Keputusan Pembelian.

f. Menguji dan menganalisis pengaruh secara tidak langsung Eco-Literacy terhadap Keputusan Pembelian.

g. Menguji dan menganalisis pengaruh secara tidak langsung Green Product Knowledge terhadap Keputusan Pembelian.

Masalah yang akan dikaji dalam penelitian ini adalah :

a. Apakah Eco-Literacy berpengaruh secara langsung terhadap Green Lifestyle.

b. Apakah Green Product Knowledge berpengaruh secara langsung terhadap Green Lifestyle.

c. Apakah Eco-Literacy berpengaruh secara langsung terhadap Keputusan Pembelian.

d. Apakah Green Product Knowledge berpengaruh secara langsung terhadap Keputusan Pembelian.

e. Apakah Green Lifestyle berpengaruh secara langsung terhadap Keputusan Pembelian.

f. Apakah Eco-Literacy berpengaruh secara tidak langsung terhadap Keputusan Pembelian melalui Green Lifestyle.

g. Apakah Green Product Knowledge berpengaruh secara tidak langsung terhadap Keputusan Pembelian melalui Green Lifestyle.

Dalam penelitian ini, hipotesis yang akan diuji adalah sebagai berikut :

a. Eco-Literacy berpengaruh secara langsung terhadap Green Lifestyle.

b. Eco-Literacy berpengaruh secara langsung terhadap Keputusan Pembelian.

c. Green Product Knowledge berpengaruh secara langsung terhadap Green Lifestyle.

d. Green Product Knowledge berpengaruh secara langsung terhadap Keputusan Pembelian

e. Green Lifestyle berpengaruh positif dan signifikan terhadap Keputusan Pembelian

f. Eco-Literacy berpengaruh secara tidak langsung terhadap Keputusan Pembelian melalui Green Lifestyle.

g. Green Product Knowledge berpengaruh secara tidak langsung terhadap Keputusan Pembelian melalui Green Lifestyle.

\section{Metode}

Variabel yang digunakan dalam penelitian ini terdiri dari variabel dependen, variabel moderasi dan variabel independen. Variabel dependen dalam penelitian ini adalah keputusan pembelian $\left(\mathrm{Y}_{2}\right)$ yaitu kesediaan konsumen untuk memilih produk tertentu guna memenuhi kebutuhan dan keinginannya dari sejumlah alternatif yang tersedia. Variabel moderasi adalah Green Lifestyle $\left(\mathrm{Y}_{1}\right)$, yaitu gaya hidup konsumen yang ramah lingkungan. Sedangkan variabel independen adalah Ecoliteracy $\left(\mathrm{X}_{1}\right)$ dan Green Product Knowledge $\left(\mathrm{X}_{2}\right)$. Ecoliteracy adalah cara berpikir konsumen terkait dengan lingkungan ekologi di sekitarnya. Green Product Knowledge adalah tingkat pengetahuan konsumen terhadap produk ramah lingkungan.

Populasi penelitian ini adalah konsumen di Kota Ambon yang menggunakan green product. Sampel penelitian ini adalah konsumen yang ditemui saat pengambilan data dengan teknik accidental sampling. Jumlah sampel penelitian ini adalah sebanyak 100 orang, yang ditemui saat membeli green product di 4 toko swalayan di Kota Ambon. Pengumpulan data penelitian ini menggunakan kuesioner yang disusun berdasarkan Skala Likert dengan skor jawaban antara 1 sampai dengan 5. Pengambilan data dilakukan selama satu minggu di mana setiap swalayan pengambilan data dilakukan selama 2 jam sehari.

Validitas suatu alat ukur adalah apakah suatu alat ukur dapat mengukur apa yang sebenarnya ingin diukur (Cooper, 2003). Uji validitas dilakukan dengan menganalisis valid tidaknya sub variabel yang digunakan sebagai pengukuran dan selanjutnya dari sub variabel yang valid dilakukan analisis butir untuk melihat butir yang valid melalui penggunaan SPSS versi 21. Selanjutnya untuk menguji validitas setiap konstruk, dalam hal ini convergent validity digunakan confirmatory factor analysis (CFA). 
Pengukuran convergent validity suatu instrumen riset dikatakan memenuhi convergent validity jika nilai loading setiap item atau indikator terhadap konstruk yang diukurnya adalah $\geq 0,4$. rule of thumb menyatakan bahwa penerimaan skor factor loading adalah $\geq 0,4$ dan secara tegas mengukur konstruk (Hair, 1998).

Reliabilitas dari suatu pengukuran mencerminkan apakah suatu pengukuran terbebas dari kesalahan (error) sehingga akan memberikan hasil pengukuran yang konsisten pada kondisi yang berbeda dan pada masing-masing butir dalam instrumen (Sekaran, 2003). Dalam hal ini reliabilitas konstruk diukur dengan menggunakan item to total correlation dan Cronbach's Alpha, yang mencerminkan konsistensi internal suatu alat ukur. Rules of thumb yang digunakan adalah item to total correlaton masing-masing butir harus lebih besar dari 0,5. Sedangkan Cronbach's alpha harus lebih besar dari 0.7, meskipun nilai 0.6 masih dapat diterima (Hair, 1998). Pengukuran reliabilitas dilakukan untuk masing-masing konstruk secara terpisah.

Sebelum melakukan uji analisa jalur maka dilakukan uji asumsi klasik yang terdiri dari :

a. Uji Normalitas data.

Pengujian normalitas data bertujuan untuk menguji apakah dalam model regresi variabel pengganggu atau residual memiliki distribusi normal (Imam, 2005). Uji T dan uji F mengasumsikan bahwa nilai residual terdistribusi secara normal. Apabila, asumsi tersebut tidak terpenuhi maka uji statistik tidak valid untuk jumlah sampel yang kecil. Cara yang dipergunakan untuk menguji normalitas data dalam penelitian ini adalah dengan mengunakan uji non-parametrik Kolmogorof Smirnov test.

b. Uji Multikolinearitas.

Pengujian multikolinearitas dilakukan untuk melihat ada tidaknya korelasi antar variabel independen. Model regresi yang baik seharusnya tidak terjadi korelasi di antara variabel indipenden. Apabila nilai tolerance lebih dari 0,1 atau variance inflation factor (VIF) kurang dari 10 dapat dikatakan model regresi tidak terjadi multikolinearitas (Hair, 1998). Tolerance mengukur variabilitas variabel independen yang terpilih yang tidak dijelaskan oleh variabel independen lainnya.

c. Uji Heteroskadisitas

Pengujian heteroskadisitas bertujuan untuk mengetahui apakah dalam model regresi terjadi ketidaksamaan varians dari residual satu pengamatan ke pengamatan yang lain (Imam, 2005). Jika varians dari residual satu pengamatan ke pengamatan lain tetap maka disebut homoskedastisitas dan jika berbeda disebut dengan heteroskedatisitas. Model regresi yang baik adalah yang homoskedastisitas. Cara yang dipergunakan untuk uji heteroskedastisitas adalah dengan melihat grafik plot antara nilai prediksi variabel terikat (dependen) yaitu ZPRED dengan residualnya SRESID. Jika ada pola tertentu, seperti titik - titik yang ada membentuk pola tertentu yang teratur (bergelombang, melebar kemudian menyempit), maka mengindikasikan telah terjadi heteroskedastisitas (Imam, 2005).

Pengujian hipotesis dengan menggunakan analisis jalur di mana analisis ini mengukur pengaruh antar variable dalam penelitian. Analisis jalur ialah suatu teknik untuk menganalisis hubungan sebab akibat yang tejadi pada regresi berganda jika variabel bebasnya mempengaruhi variabel tergantung tidak hanya secara langsung tetapi juga secara tidak langsung" (Imam, 2005). Pengujian dilakukan dengan menggunakan analisis jalur karena variabel independen dan variabel dependen yang dianalisis secara bersama-sama. Perhitungan dan pengujian dalam penelitian ini digunakan program statistik SPSS 21.

Persamaan struktural yang digunakan dalam penelitian ini adalah sebagai berikut.

$Y_{1}=P Y_{1} X_{1}+P Y_{1} X_{2}+\varepsilon_{1}$

$Y_{2}=P Y_{2} X_{1}+P Y_{2} X_{2}+P Y_{2} Y_{1}+\varepsilon_{2}$

Di mana :

$\mathrm{X}_{1}=$ Ecoliteracy

$\mathrm{X}_{2}=$ Green Product Knowledge 
$\mathrm{Y}_{1}=$ Green Lifestyle

$\mathrm{Y}_{2}=$ Keputusan Pembelian

e1,e2 = Error term

$\mathrm{p}=$ koofisien jalur

\section{Hasil dan Pembahasan}

\subsection{Karakteristik Responden}

Responden penelitian ini adalah 100 orang konsumen yang ditemui saat melakukan pembelian produk ramah lingkungan di empat swalayan di Kota Ambon. Mereka terdiri dari 44 orang (44\%) laki-laki dan 55 orang $(55 \%)$ perempuan yang telah menggunakan produk ramah lingkungan antara 5-10 tahun sebanya 54 orang (54\%), kurang dari 5 tahun sebanyak 28 orang (28\%) dan lebh dari 10 tahun sebanyak 18 orang $(18 \%)$. Selanjutnya responden penelitian ini sebagian besar memiliki tingkat pendidikan sarjana sebanyak 26 orang (26\%), diploma sebanyak 23 orang (23\%), Pascasarjana dan SMA/sederajat masing-masing sebanyak 20 orang (20\%) sedangkan selebihnya sebanyak 11 orang memiliki tingkat pendidikan lainnya. Dari jenis pekerjaan, responden penelitian ini yang bekerja sebagai pegawai negeri sipil sebanyak 58 orang (58\%), pegawai sasta sebanyak 26 orang $(26 \%)$ dan selebihnya memiliki jenis pekerjaan lainnya, seperti pelajar, mahasiswa dan sebagainya. Sementara itu, responden penelitian ini

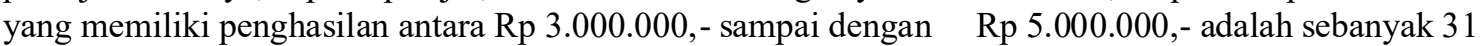
orang $(31 \%)$ dan selebihnya adalah mereka yang memiliki penghasilan kurang dari $\mathrm{Rp} 3.000 .000$,sebanyak 13 orang $(13 \%)$.

\subsection{Hasil Penelitian}

3.2.1. Hasil Uji Validitas dan Reliabilitas Instrumen

Hasil pengujian validitas data yang dikumpulkan melalui kuesioner ini menunjukan semua pernyataan yang digunakan dalam kuesioner adalah valid, yang ditunjukan melalui nilai koefisien korelasi Spearman $>0.370$ dan nilai sgnifikansi 0,000 . Selanjutnya hasil pengujian reliabilitas menunjukan semua instrumen yang digunakan untuk mengukur masing-masing variabel adalah reliabel, yang ditunjukan melalui nilai Cronbach Alpha $>0.060$. dengan demikian maka instrumen yang digunakan dalam pengumpulan data penelitian ini adalah valid dan reliabel.

\subsubsection{Hasil Uji Asumsi Jalur}

Hasil pengujian normalitas data penelitian ini menunjukan bahwa data penelitian ini terdistribusi secara normal, yang ditunjukan melalui bentuk kurva distribusi yang berbentuk lonceng. Demikian pula dengan grafik normal probability plot memperlihatkan penyebaran titik-titik disekitar garis diagonal dan penyebarannya mengikuti arah garis diagonal. Hasil pengujian heteroskedastisitas menunjukan tidak ada gejala heteroskedastisitas dari data penelitian ini, yang ditunjukan melalui titik-titik yang menyebar secara acak dan sebarannya berada di atas maupun di bawah angka nol pada sumbu Y.

Hasil pengujian autokorelasi menunjukan data penelitian ini memiliki gejala autokorelasi positif, di mana nilai DW berada di antara nilai $\mathrm{dU}$ dan $\mathrm{dL}$, yang berarti bahwa persamaan regresi berganda yang dihasilkan dari penelitian ini bersifat linier. Selanjutnya hasil pengujian multikolinearitas menunjukan tidak adanya gejala multikolinearitas yang ditunjukan melalui nilai VIF yang kurang dari 10.

\subsubsection{Hasil Analisis Jalur}

Analisis jalur digunakan untuk mengukur besarnya kontribusi atau pengaruh variabel bebas terhadap variabel terikat, baik pengaruh langsung maupun pengaruh tidak langsung melalui hubungan dengan variabel bebas lainnya. Dalam menggunakan analisis jalur, beberapa asumsi yang digunakan adalah sebagai berikut.

1) Hubungan antar variabel bersifat linier, yang berarti bahwa dengan adanya perubahan satu variabel akan terus diikuti dengan perubahan variabel lain dengan arah yang tetap.

2) Semua variabel residu tidak berkorelasi antara yang satu dengan yang lain, artinya variabel bebas tidak akan mampu mempengaruhi variabel terikat secara sempurna sehingga akan memiliki nilai residu yang merupakan besarnya pengaruh dari variabel bebas yang tidak diteliti.

3) Pola hubungan antar variabel adalah rekrusif, artinya hubungan antar variabel adalah searah atau hubungan antara satu variabel dengan variabel lainnya tidak bersifat timbal balik (resiprok). 
Dari hasil komputasi menggunakan SPSS 21, dapatlah dikemukakan hasil pengujian untuk persamaan struktural 1 adalah sebagai berikut.

Tabel 1 : Model Summary Persamaan 1

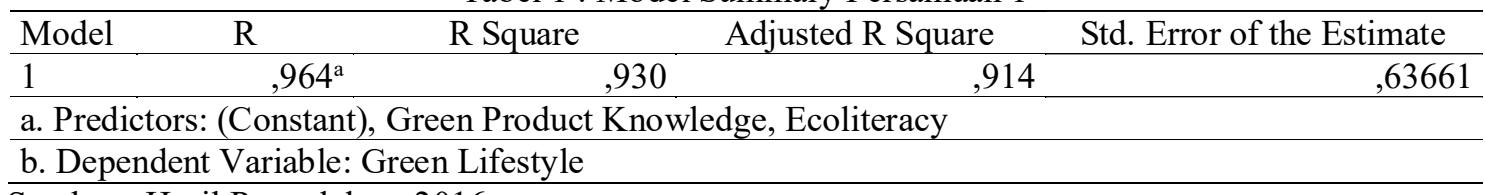

Sumber : Hasil Pengolahan, 2016

Berdasarkan hasil tersebut, dapat dijelaskan bahwa besarnya korelasi atau hubungan antara variabel ecoliteracy $\left(\mathrm{X}_{1}\right)$ dan green product knowledge $\left(\mathrm{X}_{2}\right)$ dengan green lifestyle $\left(\mathrm{Y}_{1}\right)$ adalah sebesar 0,964 atau $96,4 \%$. Hal ini berarti bahwa ecoliteracy dan green product knowledge secara gabungan memiliki hubungan yang erat dengan green lifestyle konsumen di Kota Ambon sebesar 96,4 \%. Hal ini ditunjukan melalui nilai $\mathrm{R}$ atau Multiple $R$ sebesar 0,964.

Selanjutnya nilai $R$ Square $\left(\mathrm{R}^{2}\right)$ atau koefisien determinasi sebesar 0,930 menunjukan bawah besarnya variasi green lifestyle dapat dijelaskan secara bersama-sama oleh ecoliteracy dan green product knowledge sebesar 93,0 \%. Dengan kata lain, variabilitas green lifestyle yang dapat diterangkan dengan menggunakan variabel ecoliteracy dan green product knowledge adalah sebesar 93,0\%. Dengan demikian, green lifestyle dipengaruhi secara bersama-sama oleh ecoliteracy dan green product knowledge sebesar 93,0\%, sedangkan pengaruh sebesar 7,0\% disebabkan oleh variabel-variabel lain di luar model penelitian ini.

Nilai Adjusted $R$ Square sebesar 0,914 menunjukan besarnya pengaruh ecoliteracy dan green product knowledge terhadap green lifestyle konsumen di Kota Ambon sebesar 91,4 \% yang telah dikoreksi dengan jumlah variabel dan besarnya sampel sehingga dapat mengurangi unsur bias jika terjadi penambahan variabel. Nilai standard error of the estimate sebesar 0,63661 menunjukan penyimpangan antara persamaan regresi dengan nilai dependen riilnya sebesar 0,63661 satuan variabel tergantung.

Selanjutnya untuk melakukan pengujian hipotesis (a) dan (b) dalam penelitian ini dikemukakan hasil komputasi berupa koefisien persamaan struktural 1 dalam tabel berikut.

Tabel 2 : Coefficient Persamaan Struktural 1

\begin{tabular}{|c|c|c|c|c|c|c|}
\hline \multirow[t]{2}{*}{ Model } & & \multicolumn{2}{|c|}{ Unstandardized Coefficients } & $\begin{array}{l}\text { Standardized } \\
\text { Coefficients }\end{array}$ & \multirow[t]{2}{*}{$\mathrm{t}$} & \multirow[t]{2}{*}{ Sig. } \\
\hline & & B & Std. Error & Beta & & \\
\hline \multirow{3}{*}{1} & (Constant) & 3,164 &, 639 & & 4,955 &, 000 \\
\hline & Ecoliteracy &, 683 & ,126 & ,635 & 5,421 & 000 \\
\hline & Green Product & ,787 & , 118 & ,725 & 6,669 &, 000 \\
\hline
\end{tabular}

a. Dependent Variable: Green Lifestyle

Sumber : Hasil Pengolahan, 2016

Dari data dalam tabel 2 di atas diketahui bahwa besarnya nilai konstanta adalah 3,164 yang menunjukan apabila tidak ada pengaruh variabel ecoliteracy dan green product knowledge maka besarnya nilai variabel green lifestyle adalah 3,164 atau 316,4\%. Selanjutnya besarnya nilai koefisien standar variabel ecoliteracy 0,635 menunjukan besarnya pengaruh variabel ecoliteracy terhadap green lifestyle konsumen di Kota Ambon adalah 0,635 atau 63,5\%. Nilai koefisien standar variabel green product knowledge sebesar 0,725 menunjukan besarnya pengaruh variabel green product knowledge terhadap green lifestyle konsumen di Kota Ambon sebesar 0,725 atau 72,5\%. 
Berdasarkan hasil pengujian sebagaimana disajikan pada tabel 2, diketahui bahwa besarnya nilai thitung untuk variabel ecoliteracy adalah 5,421 dengan taraf signifikansi adalah 0,000. Besarnya nilai ttabel pada derajat kebebasan $\mathrm{n}-2=100-2=98$ dengan nilai $\mathrm{a}=0,05$ adalah sebesar 2,63 sehingga diketahui bahwa nilai t-hitung $>\mathrm{t}$-tabel sehingga $\mathrm{H} 0$ ditolak dan $\mathrm{Ha}$ diterima, artinya terdapat pengaruh variabel ecoliteracy $\left(\mathrm{X}_{1}\right)$ terhadap green lifestyle $\left(\mathrm{Y}_{1}\right)$ konsumen di Kota Ambon. Hal ini juga diperkuat dengan melihat besarnya nilai signifikansi variabel ecoliteracy sebesar $0,000<\mathrm{a}(0,05)$. Dengan demikian maka besarnya pengaruh variabel ecoliteracy terhadap green lifestyle sebesar 0,635 atau 63,5 $\%$ adalah signifikan, sehingga hipotesa (a) yang diajukan dalam penelitian ini diterima, di mana ecoliteracy berpengaruh secara langsung terhadap green lifestyle konsumen di Kota Ambon.

Berdasarkan hasil pengujian pada tabel 2, diketahui bahwa besarnya nilai t-hitung untuk variabel green product knowledge (X2) adalah 6,669 dengan taraf signifikansi adalah 0,000. Besarnya nilai t-tabel pada derajat kebebasan $n-2=100-2=98$ dengan nilai a $=0,05$ adalah sebesar 2,63 sehingga diketahui bahwa nilai t-hitung $>$ t-tabel sehingga $\mathrm{H} 0$ ditolak dan Ha diterima, artinya terdapat pengaruh variabel green product knowledge $\left(\mathrm{X}_{2}\right)$ terhadap green lifestyle $\left(\mathrm{Y}_{1}\right)$ konsumen di Kota Ambon. Hal ini juga diperkuat dengan melihat besarnya nilai signifikansi variabel green product knowledge (X2) sebesar $0,000<\mathrm{a}$ $(0,05)$. Dengan demikian besarnya pengaruh variabel green product knowledge terhadap green lifestyle sebesar 0,725 atau 72,5\% dianggap signifikan, sehingga hipotesa (b) yang diajukan dalam penelitian ini dapat diterima, di mana green product knowledge berpengaruh positif dan signifikan terhadap green lifestyle konsumen di Kota Ambon.

Selanjutnya dari hasil komputasi menggunakan SPSS 21, dapatlah dikemukakan hasil pengujian untuk persamaan struktural 2 adalah sebagai berikut.

Tabel 3 : Model Summary Persamaan 2

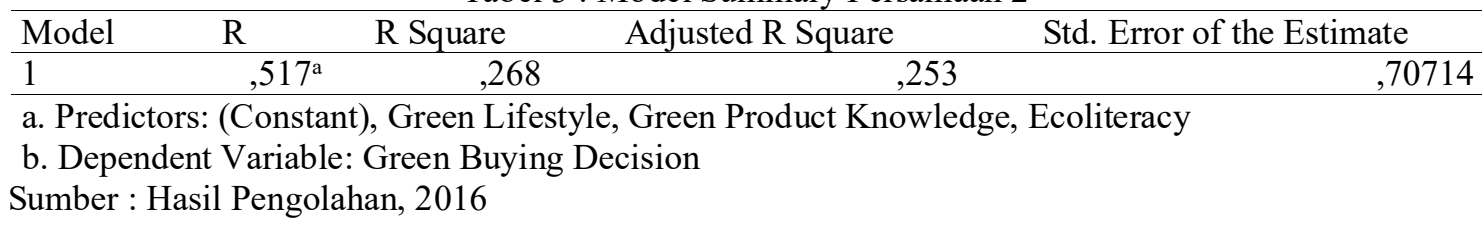

Berdasarkan hasil tersebut, dapat dijelaskan bahwa besarnya korelasi atau hubungan antara variabel ecoliteracy $\left(\mathrm{X}_{1}\right)$, green product knowledge $\left(\mathrm{X}_{2}\right)$ dan green lifestyle $\left(\mathrm{Y}_{1}\right)$ dengan keputusan pembelian $\left(\mathrm{Y}_{2}\right)$ adalah sebesar 0,517 atau $51,7 \%$. Hal ini berarti bahwa ecoliteracy, green product knowledge dan green lifestyle secara gabungan memiliki hubungan yang erat dengan keputusan pembelian konsumen di Kota Ambon sebesar 51,7 \%. Hal ini ditunjukan melalui nilai $\mathrm{R}$ atau Multiple $R$ sebesar 0,517. Selanjutnya nilai $R$ Square $\left(\mathrm{R}^{2}\right)$ atau koefisien determinasi sebesar 0,268 menunjukan bawah besarnya variasi keputusan pembelian konsumen di Kota Ambon dapat dijelaskan secara bersama-sama oleh ecoliteracy, green product dan knowledge green lifestyle sebesar 26,8 \%. Dengan kata lain, variabilitas keputusan pembelian konsumen yang dapat diterangkan dengan menggunakan variabel ecoliteracy, green product knowledge dan green lifestyle adalah sebesar 26,8 \%. Dengan demikian, keputusan pembelian konsumen dipengaruhi secara bersama-sama oleh ecoliteracy, green product knowledge dan green lifestyle sebesar 26,8 \%, sedangkan pengaruh sebesar 73,2 \% disebabkan oleh variabel-variabel lain di luar model penelitian ini. Nilai Adjusted $R$ Square sebesar 0,253 menunjukan besarnya pengaruh ecoliteracy, green product knowledge dan green lifestyle terhadap keputusan pembelian konsumen di Kota Ambon sebesar 25,3\% yang telah dikoreksi dengan jumlah variabel dan besarnya sampel sehingga dapat mengurangi unsur bias jika terjadi penambahan variabel. Nilai standard error of the estimate sebesar 0,70714 menunjukan penyimpangan antara persamaan regresi dengan nilai dependen riilnya sebesar 0,70714 satuan variabel tergantung.

Selanjutnya untuk melakukan pengujian hipotesis (c) - (e) dalam penelitian ini dikemukakan hasil komputasi berupa koefisien persamaan struktural 2 dalam tabel berikut. 
Tabel 4 : Coefficient Persamaan Struktural 2

\begin{tabular}{|c|c|c|c|c|c|c|}
\hline \multicolumn{2}{|c|}{ Model } & \multicolumn{2}{|c|}{ Unstandardized Coefficients } & \multirow{2}{*}{$\begin{array}{c}\text { Standardized } \\
\text { Coefficients }\end{array}$} & \multirow[t]{2}{*}{$\mathrm{t}$} & \multirow[t]{2}{*}{ Sig. } \\
\hline & & B & Std. Error & & & \\
\hline \multirow{4}{*}{1} & (Constant) & 4,035 & ,686 & & 5,879 & , 000 \\
\hline & Ecoliteracy & ,728 & ,123 & ,707 & 5,044 & ,000 \\
\hline & $\begin{array}{l}\text { Green Product } \\
\text { Knowledge }\end{array}$ & ,611 &, 113 & ,581 & 5,407 &, 000 \\
\hline & Green Lifestyle & 695 & ,097 &, 599 & 7,165 &, 000 \\
\hline
\end{tabular}

a. Dependent Variable: Green Buying Decision

Sumber : Hasil Pengolahan, 2016

Dari data dalam tabel 4 di atas diketahui bahwa besarnya nilai konstanta adalah 4,035 yang menunjukan apabila tidak ada pengaruh variabel ecoliteracy, green product knowledge dan green lifestyle maka besarnya nilai variabel keputusan pembelian adalah 4,035 atau 430,5\%. Selanjutnya besarnya nilai koefisien standar variabel ecoliteracy 0,707 menunjukan besarnya pengaruh variabel ecoliteracy terhadap keputusan pembelian konsumen di Kota Ambon adalah 0,707 atau 70,7 \%. Nilai koefisien standar variabel green product knowledge sebesar 0,581 menunjukan besarnya pengaruh variabel green product knowledge terhadap keputusan pembelian konsumen di Kota Ambon sebesar 0,581 atau 58,1 $\%$. Nilai koefisien standar variabel green lifestyle sebesar 0,599 menunjukan besarnya pengaruh variabel green lifestyle terhadap keputusan pembelian konsumen di Kota Ambon sebesar 0,599 atau 59,9 \%.

Berdasarkan hasil pengujian sebagaimana disajikan pada tabel 4 , diketahui bahwa besarnya nilai thitung untuk variabel ecoliteracy adalah 5,044 dengan taraf signifikansi adalah 0,000. Besarnya nilai ttabel pada derajat kebebasan $\mathrm{n}-2=100-2=98$ dengan nilai $\mathrm{a}=0,05$ adalah sebesar 2,63 sehingga diketahui bahwa nilai t-hitung $>\mathrm{t}$-tabel sehingga $\mathrm{H} 0$ ditolak dan $\mathrm{Ha}$ diterima, artinya terdapat pengaruh variabel ecoliteracy $\left(\mathrm{X}_{1}\right)$ terhadap keputusan pembelian $\left(\mathrm{Y}_{2}\right)$ konsumen di Kota Ambon. Hal ini juga diperkuat dengan melihat besarnya nilai signifikansi variabel ecoliteracy sebesar $0,000<\mathrm{a}(0,05)$. Dengan demikian maka besarnya pengaruh variabel ecoliteracy terhadap keputusan pembelian sebesar 0,707 atau 70,7 \% adalah signifikan, sehingga hipotesa (c) yang diajukan dalam penelitian ini diterima, di mana ecoliteracy berpengaruh secara langsung terhadap keputusan pembelian konsumen di Kota Ambon.

Berdasarkan hasil pengujian pada tabel 4, diketahui bahwa besarnya nilai t-hitung untuk variabel green product knowledge $\left(\mathrm{X}_{2}\right)$ adalah 5,407 dengan taraf signifikansi adalah 0,000 . Besarnya nilai t-tabel pada derajat kebebasan $\mathrm{n}-2=100-2=98$ dengan nilai a $=0,05$ adalah sebesar 2,63 sehingga diketahui bahwa nilai t-hitung $>\mathrm{t}$-tabel sehingga $\mathrm{H} 0$ ditolak dan Ha diterima, artinya terdapat pengaruh variabel green product knowledge $\left(\mathrm{X}_{2}\right)$ terhadap keputusan pembelian $\left(\mathrm{Y}_{2}\right)$ konsumen di Kota Ambon. Hal ini juga diperkuat dengan melihat besarnya nilai signifikansi variabel green product knowledge $\left(\mathrm{X}_{2}\right)$ sebesar $0,000<\mathrm{a}(0,05)$. Dengan demikian besarnya pengaruh variabel green product knowledge terhadap keputusan pembelian sebesar 0,581 atau 58,1 \% dianggap signifikan, sehingga hipotesa (d) yang diajukan dalam penelitian ini dapat diterima, di mana green product knowledge berpengaruh secara langsung terhadap keputusan pembelian konsumen di Kota Ambon.

Berdasarkan hasil pengujian pada tabel 4, diketahui bahwa besarnya nilai t-hitung untuk variabel green lifestyle $\left(\mathrm{Y}_{1)}\right.$ adalah 7,165 dengan taraf signifikansi adalah 0,000 . Besarnya nilai t-tabel pada derajat kebebasan $\mathrm{n}-2=100-2=98$ dengan nilai a $=0,05$ adalah sebesar 2,63 sehingga diketahui bahwa nilai thitung $>\mathrm{t}$-tabel sehingga $\mathrm{H} 0$ ditolak dan Ha diterima, artinya terdapat pengaruh variabel green lifestyle $\left(\mathrm{Y}_{1}\right)$ terhadap keputusan pembelian $\left(\mathrm{Y}_{2}\right)$ konsumen di Kota Ambon. Hal ini juga diperkuat dengan melihat besarnya nilai signifikansi variabel green lifestyle $\left(Y_{1}\right)$ sebesar $0,000<$ a $(0,05)$. Dengan demikian besarnya pengaruh variabel green lifestyle terhadap keputusan pembelian sebesar 0,599 atau $59,9 \%$ dianggap signifikan, sehingga hipotesa (e) yang diajukan dalam penelitian ini dapat diterima, di mana green lifestyle berpengaruh secara langsung terhadap keputusan pembelian konsumen di Kota Ambon. 
Untuk melakukan pengujian hipotesis $f$ dan $g$ yang diajukan dalam penelitian ini maka telah mengetahui besarnya pengaruh langsung (direct effect) variabel ecoliteracy $\left(\mathrm{X}_{1}\right)$ terhadap green lifestyle $\left(\mathrm{Y}_{1}\right)$ adalah sebesar 0,635 . Besarnya pengaruh variabel green product knowledge $\left(\mathrm{X}_{2}\right)$ terhadap green lifestyle $\left(\mathrm{Y}_{1}\right)$ adalah 0,725 . Selanjutnya besarnya pengaruh variabel ecoliteracy $\left(\mathrm{X}_{1}\right)$ terhadap keputusan pembelian konsumen $\left(\mathrm{Y}_{2}\right)$ adalah sebesar 0,707 . Besarnya pengaruh variabel green product knowledge $\left(\mathrm{X}_{2}\right)$ terhadap keputusan pembelian konsumen $\left(\mathrm{Y}_{2}\right)$ adalah 0,581 serta besarnya pengaruh variabel green lifestyle $\left(\mathrm{Y}_{1}\right)$ terhadap keputusan pembelian konsumen $\left(\mathrm{Y}_{2}\right)$ adalah 0,599. Selanjutnya besarnya pengaruh tidak langsung (indirect effect) variabel ecoliteracy $\left(\mathrm{X}_{1}\right)$ terhadap keputusan pembelian konsumen $\left(\mathrm{Y}_{2}\right)$ melalui green lifestyle $\left(\mathrm{Y}_{1}\right)$ adalah $0,635 \times 0,599=0,380$. Dengan demikian maka dapat diketahui bahwa ecoliteracy berpengaruh secara tidak langsung terhadap keputusan pembelian konsumen melalui green lifestyle, sehingga hidpotesis (f) yang diajukan dalam penelitian ini dapat diterima. Selanjutnya besarnya pengaruh variabel green product knowledge $\left(\mathrm{X}_{2}\right)$ terhadap keputusan pembelian konsumen $\left(\mathrm{Y}_{2}\right)$ melalui green lifestyle $\left(\mathrm{Y}_{1}\right)$ adalah $0,725 \times 0,599=0,434$. Dengan demikian maka dapat diketahui bahwa green product knowledge berpengaruh secara tidak langsung terhadap keputusan pembelian konsumen melalui green lifestyle, sehingga hipotesis (g) yang diajukan dalam penelitian ini dapat diterima.

\subsection{Pembahasan}

Hasil penelitian ini menunjukan bahwa semua variabel bebas memiliki pengaruh terhadap variabel terikat. Ecoliteracy dan green product knowledge memiliki pengaruh secara langsung terhadap green lifestyle dan keputusan pembelian. Selanjutnya green lifestyle memiliki pengaruh secara langsung terhadap keputusan pembelian konsumen di Kota Ambon. Demikian pula ecoliteracy dan green product knowledge memiliki pengaruh secara tidak langsung terhadap keputusan pembelian melalui green lifestyle.

Hasil penelitian ini menunjukan bahwa pengaruh secara langsung ecoliteracy dan green product knowledge ternyata lebih besar daripada pengaruh tidak langsung melalui green lifestyle. Hal ini berarti bahwa keputusan konsumen untuk melakukan pembelian suatu green product lebih banyak dipengaruhi oleh ecoliteracy dan green product knowledge daripada green lifestyle. Oleh karena itu, untuk bisa mendorong konsumen secara lebih luas untuk melakukan pembelian terhadap green product, akan lebih baik dan lebih mudah bagi pemasar dan atau produsen untuk meningkatkan ecoliteracy dan green product knowledge dari konsumen.

Green lifestyle adalah gaya hidup yang ramah terhadap lingkungan, dan hasil penelitian ini menunjukan bahwa gaya hidup tersebut secara langsung memiliki pengaruh yang positif terhadap keputusan pembelian konsumen. Namun demikian green lifestyle bukan merupakan mediator yang baik bagi ecoliteracy dan green product knowledge dalam pengambilan keputusan konsummen atas produk yang ramah lingkungan. Gaya hidup cenderung bersifat tetap, sehingga untuk merubahnya membutuhkan waktu lama dan usaha yang tidak ringan. Oleh karena itu, pemasar dan atau produsen akan lebih mudah memengaruhi pengambilan keputusan pembelian konsumen melalui ecoliteracy dan green product knowledge.

Hasil penelitian ini sejalan dengan penelitian yang dilakukan oleh Astuti (2013) dan Jaolis (2011), yang membuktikan bahwa variabel ecoliteracy berpengaruh signifikan terhadap green purchasing. Dengan adanya pengetahuan mengenai ecoliteracy dapat mendorong seseorang untuk melakukan green purchasing karena sadar akan pentingnya menjaga keseimbangan antara lingkungan dan juga kebutuhan sehari-hari.

\section{Kesimpulan}

Penelitian ini bertujuan untuk menguji dan menganalisis pengaruh ecoliteracy, green product knowledge terhadap green lifestyle dan keputusan pembelian, baik secara langsung maupun tidak langsung. Hasil penelitian ini menunjukan bahwa semua variabel bebas memiliki pengaruh terhadap variabel terikat. Ecoliteracy dan green product knowledge memiliki pengaruh secara langsung terhadap green lifestyle dan keputusan pembelian. Selanjutnya green lifestyle memiliki pengaruh secara langsung terhadap 
keputusan pembelian konsumen di Kota Ambon. Demikian pula ecoliteracy dan green product knowledge memiliki pengaruh secara tidak langsung terhadap keputusan pembelian melalui green lifestyle.

\section{Ucapan Terima Kasih}

Para penulis mengucapkan terima kasih kepada semua responden yang sudah berkontribusi dalam penelitian ini melalui pengisian kuesioner penelitian yang dibagikan. Demikian pula kepada pemilik toko swalayan yang sudah mengijinkan penulis untuk melakukan pengambilan data penelitian ini.

\section{Daftar Pustaka}

Tilikidou, I. (2008) 'Ecological Marketing: A Research Approach', Sofia Publications, Thessaloniki.

Capra, F. (2011) 'Ecological Literacy', Journal of Draft Global Issues Pilot, August (1-15)

Orr, D. (2011) 'Hope Is an Imperative: The Essential David Orr, Washington, DC: Island Press

Lorenzen, Janet A. (2012) 'Going Green: The Process of Lifestyle Change', Sociological Forum, Vol. 27, No. 1, March 2012

Cooper, D.R. dan Schindler, P.S. 2003. Business Research Methods, Edisi ke-8, New York: McGraw Hill

Hair, J. F., Anderson, R. E., Tatham, R. L., \& William, C. (1998) 'Multivariate data analysis', Black and Willey Sekaran, U., and Bougie, R. (2003) 'Research methodology for business'

Imam, G. (2005) 'Aplikasi Analisis Multivariate dengan Program SPSS' Semarang: Badan Penerbit Universitas Diponegoro.

Astuti, N. (2013) 'Pengaruh Ecoliteracy, Pengaruh Interpersonal dan Orientasi Nilai pada Kesediaan Membeli Melalui Sikap Konsumen Terhadap Produk Ramah Lingkungan (Studi Empiris pada Konsumen Tupperware di Yogyakarta)', Skripsi tidak Dipublikasikan

Jaolis, F. (2011) 'Profil Green Consumers Indonesia : Identifikasi Segmen dan Faktor-Faktor yang Mempengaruhi Perilaku Pembelian Green Products’ Jurnal Mitra Ekonomi dan Manajemen Bisnis, Vol. 2, (18-39). 